The Effects of Firm Size on Job Quality: A Comparative Study for Britain and France

Alex Bryson

Christine Erhel

Zinaïda Salibekyan

Department of Quantitative Social Science

Working Paper No. 17-08

April 2017 


\section{Disclaimer}

Any opinions expressed here are those of the author(s) and not those of the UCL Institute of Education. Research published in this series may include views on policy, but the institute itself takes no institutional policy positions.

DoQSS Workings Papers often represent preliminary work and are circulated to encourage discussion. Citation of such a paper should account for its provisional character. A revised version may be available directly from the author.

Department of Quantitative Social Science, UCL Institute of Education, University College London, 20 Bedford Way, London WC1H 0AL, UK 


\title{
The Effects of Firm Size on Job Quality: A Comparative Study for Britain and France
}

\author{
Alex Bryson ${ }^{1}$, Christine Erhel $^{2}$ and Zinaïda Salibekyan ${ }^{3}$
}

\section{Abstract}

Using linked employer-employee data from two comparable surveys this article examines the links between non-pecuniary job quality and workplace characteristics in Britain and France - countries with very different employment regimes. The results show that job quality is better in Britain than it is in France, despite its minimalist regulatory regime. The difference is apparent for all dimensions of job quality (skill development, training participation, job autonomy, job insecurity, work-life balance and relations between employers and employees), except skills' match to a job. Firm size is negatively associated with non-pecuniary job quality in both countries but in France the association is confined to only the largest firms. Internal Labour Markets (ILMs) are associated with higher job quality in France, but not in Britain.

JEL codes: I31; J30; J81

Keywords: Job quality, Firm size, Internal labour market, Linked employer-employee data, Britain, France, Comparative

Contact Details: Alex Bryson (a.bryson@ucl.ac.uk), University College London, National Institute of Social and Economic Research and Institute for the Study of Labor

\footnotetext{
${ }^{1}$ University College London, National Institute of Social and Economic Research and Institute for the Study of Labor

${ }^{2}$ Université Paris 1 Panthéon-Sorbonne, Centre d'Economie de la Sorbonne, CEET

${ }^{3}$ CNAM, LIRSA, CEET, LEST
} 


\section{Introduction}

Job quality affects worker wellbeing (Karasek, 1979; Author A, 2016), worker productivity (Oswald et al., 2015) and thus firm performance (Author A, 2015). It is multi-faceted but its main features are well-known. It varies markedly across countries, partly reflecting differences in national institutional regimes (Gallie, 2007; Holman, 2013; Green et al., 2013). However, there is also substantial within-country variation in job quality across employees and across workplaces. The latter reflects both structural features of workplaces, such as industry affiliation, and the choices employers make regarding investments in job quality, which in turn reflect perceptions of the costs and benefits of such investments. Osterman (2013), for example, has emphasised the importance of accounting for employer decisions over working conditions when seeking to understand variance in job quality.

The article contributes to the literature by focusing on two features of workplaces that are likely to influence job quality: the size of a firm and the existence of internal labour markets (ILMs), characterized by ongoing skill development, opportunities for career progression and higher returns to seniority. This is done in a comparative context to investigate how these workplace features relate to job quality across two very different institutional contexts. The article focuses on Britain and France because they represent very different types of employment regime and because they provide data that are uniquely suited to understanding the associations between structural features of workplaces, workplace policies and practices, and job quality as experienced by employees in those workplaces. Data issues limit our ability to compare identical job quality items across Britain and France, but the indicators are sufficiently comparable to provide some indications regarding levels of job quality in the two countries. 
Three hypotheses are tested in the current study. First, job quality should be better, on average, in more highly regulated economies such as France, compared to liberal market-oriented economies like Britain. The second proposition is that job quality is negatively correlated with firm size in both countries. The third hypothesis argues that some specific features of the French regime will contribute to better job quality. These features are the presence of highly developed ILMs in French workplaces, which are often embedded in larger firms, and the existence of compulsory worker representation over a certain firm size. Contrary to expectations, the results show that job quality is better in Britain than it is in France. However, as anticipated, firm size is negatively associated with non-pecuniary job quality in both countries. In both countries job quality is significantly lower in the largest firms (those with 5,000 or more employees) than it is in the smallest firms with fewer than 50 employees). However, whereas in France there is no significant difference in job quality between small and medium sized (500-4999 employee) firms, in Britain job quality is significantly lower in the medium-sized compared with the small firms. It is possible that in France the main legal threshold (at 50 employees) (Trésor-Eco, 2016), above which firms are required to respond positively to worker demands for union delegates and work councils, helps mitigate the adverse impact of firm size, at least for medium-sized firms. The results also show that being in a firm with an ILM is associated with better non-pecuniary job quality in France but not in Britain.

The article is structured as follows. Section 2 reviews the literature, focusing on the relationship between job quality, firm size and ILMs and outlines our hypotheses. Section 3 describes the linked employer-employee data for the two countries and the empirical methodology. Section 4 presents the results. Section 5 concludes, 
reflecting on the implications of the analyses while, at the same time, drawing attention to some limitations.

\section{Literature and Hypotheses}

Job quality should be linked to the sort of employment regime workers face (Gallie, 2007;Author B, 2008). For example, the Varieties of Capitalism (VoC) literature emphasizes the importance of production regimes (Hall and Soskice, 2001). Coordinated Market Economies (CME) like France are characterized by long-term corporate investment, "Social Dialogue" and cooperative employment relations, and substantial initial vocational training, all of which are conducive to higher levels of job quality. Britain, on the other hand, as a prototypical Liberal Market Economy (LME), is characterized by a financial system imposing short-term horizons on firms and high risk taking, which is allied to a deregulated labour market and fragmented, uncoordinated employment relations, and an emphasis on general over vocational education, all of which should be conducive to lower job quality.

According to Gallie (2007), job quality also depends on the way employment regimes build power resources for labour and capital. He considers three idealtypes: inclusive, dualist and market regimes. France is a dualist employment regime, with a well-protected core of workers, surrounded by a precarious periphery. Britain exemplifies a market based employment regime, with very limited regulation and few opportunities for workers to build the power resources which might be used to generate high quality jobs.

Whether one thinks in terms of production or employment regimes it seems likely that average job quality should be lower in Britain than in France. This is the first hypothesis that the article tests. 
The expectation is also that job quality should vary with firm size in both countries. Due to their product market dominance, and thus the rents that accrue to them, larger firms may offer their workers higher job quality than might be offered in similar, smaller firms. If so, this may be a form of rent-sharing akin to the well-known wage premium linked to firm size (Oi and Idson, 1999). Larger firms also require formal policies and procedures to manage larger groups of employees efficiently whereas, in smaller firms, less formal systems may suffice. As such Human Resources departments may devote time and energy to human resource management (HRM) systems which are often equated with job quality, such as the formation of teams, payment of incentive pay, and the conscious design of more attractive jobs offering autonomy and variety.

However, there are also strong theoretical reasons to suspect that job quality deteriorates as firm size increases. Bigger firms are able to use their centralized HR resources to create systems of monitoring and supervision which may be inimical to job quality, and may choose to divide up responsibilities and tasks across workers which, in smaller firms, may be retained within the same job, thus offering task variety. Taylorist methods of scientific production were pioneered in large workplaces, such as car plants, and are notorious for deskilling workers in pursuit of profit and managerial control, thus limiting job autonomy (Edwards, 1979).

Although the theoretical literature regarding firm size and job quality may be ambiguous, the empirical literature on employee perceptions of job quality is unequivocal: employees tend to express greater satisfaction with their jobs in smaller firms (Author A, 2006; Clark and Oswald, 1996). Job satisfaction scholars argue that poor management-employee relationships in large firms are one source of such job dissatisfaction (Tansel and Gazioglu, 2013). Author A (2006) find that employee job 
quality in Britain is higher in small firms than in large firms: small firms make less use of shifts, zero hours and annual hours contracts and small firm employees are more likely to say they have high degrees of control and influence in their work when compared with employees in larger firms. The second hypothesis, therefore, is that, in spite of theoretical ambiguities regarding firm size and job quality, firm size will be negatively associated with job quality in both Britain and France.

On balance, one may suspect that job quality will be lower in larger firms for the reasons given above. However, the current study argues that features of the French employment regime may offset some of the firm size effects on job quality. This is for two reasons. First, the segmentation literature highlights the existence of ILMs within larger firms that should contribute positively to job quality as they imply better career prospects and more developed training to develop and retain core workers (Doerigner and Piore, 1971). Segmentation theory suggests the co-existence within countries of a primary sector containing better paying, more stable jobs and a secondary sector, consisting of employees with poor pay, low job security and otherwise unattractive jobs (Piore, 1978). Workplaces with an ILM-type orientation (belonging to the primary sector) may offer better job quality to their employees than workplaces that do not have an ILM orientation. If ILMs are themselves positively correlated with firm size, they may limit any adverse impact firm size has on job quality. It is therefore important to account for ILM practices when investigating links between firm size and job quality.

Recent empirical research indicates that ILMs are more embedded in French workplaces than they are in British workplaces (Author C, 2016) and may therefore play a bigger role in determining job quality in workplaces in France. The literature characterizes France as a country with strong ILMs as core workers benefit from 
employment protection, and have better opportunities for career progression within firms, and high returns to seniority (Maurice et al., 1986; Eyraud et al., 1990). On the other hand, peripheral workers in the secondary sector tend to be excluded from firms' investments in training (Marsden, 1990). In contrast to France, Britain used to be considered a country of occupational labour markets (OLM), in which employers and unions used to organize external mobility inside occupations (Eyraud et al., 1990), but it has evolved through time and today considerable responsibility is placed on individual employees.

The second reason why firm size effects may be mitigated in the French case is that firm size thresholds also feature in French law, offering employees some rights to worker representation (Fulton, 2015) and therefore some semblance of protection and job security, which might be lacking in smaller firms (Holman, 2013). Such regulations are likely to reinforce unions' ability to mobilize core employees of large firms (Culpepper, 1999; Hyman, 2001).' In France, by contrast, firms with more than 50 employees have to enable workers to appoint union delegates. It is also necessary for them to accede to employee requests for staff delegates where they have more than 10 employees, as well as a work council where they have more than 50 employees. These regulations suggest that employee bargaining power is stronger in medium-sized and larger firms in France than in small firms. This is in line with the expectations of the employment regime framework that within dualist regimes the historical involvement of organized labour is much greater in larger firms, which increases its chances of influencing working conditions and employment regulation (Holman, 2013), and therefore job quality.

Contrary to France, in market employment regimes like the UK organized labour has little involvement in decision-making within firms and its influence is uniform 
across the economy (Holman, 2013). UK unions' objectives generally do not include job protection issues (Davidsson and Emmenegger, 2013). Besides, the standard labour contract is characterized by a high level of flexibility. As a result, employers have greater flexibility to hire and fire workers in Britain than in many other European countries, and unions have less power to affect employment conditions (Green, 2013). It seems unlikely, therefore, that union bargaining power would result in firm size differences in job quality in Britain.

Firm size also matters for training policies in France where firm-funded training aims to provide better opportunities for career development (Paul, 1992). France differs from Britain in placing legal obligations on all firms, but at a higher level for larger firms (more than 10 employees) than for smaller ones. Firms with over 10 employees have to spend at least $1 \%$ of their wage bill on training (it was $1.6 \%$ before 2014), and small firms $0.55 \%$. The comparative data used in the current study do not contain workplaces with 10 employees or less, so it is not possible to test what effect, if any, this employment threshold has on training-related job quality. Nevertheless, the legal obligation to provide training in France suggests training incidence will be greater in France than Britain, where no such training requirement exists. Vocational training is also a topic for social bargaining at various levels in France (firm, branch, regions and national level).

British governments support training policies, but very few collective agreements exist on continuing training, and firms have to invest voluntarily in their workers with little regulation or subsidy (Greenhalgh, 1999; Ok and Tergeist, 2003). Although employees in larger organisations with 250 or more employees have a right to time off for training after 26 weeks' employment it is a right to unpaid time off.ii 


\section{Data and Methods}

The data come from the British Workplace Employment Relations Survey (WERS 2011) and from the French Enquête Relations Professionnelles et Négociations d'Entreprise (REPONSE 2011).iii The WERS and REPONSE linked employeremployee surveys are among the most authoritative sources of information on employment relations. Other surveys may offer broader coverage of the two economies or a larger set of harmonized data items, but the WERS and REPONSE surveys offer the unique advantage that the samples of workplaces and employees are fully linkable in each country. In order to have harmonized datasets workplaces with eleven or more employees were selected with at least 15 months of tenure and include private industries except agriculture. The surveys are based on stratified random samples so that when survey weights are applied analyses are representative for this population in both countries. The analysis uses equivalently defined samples of 3,947 workplaces and 11,244 employees from REPONSE in 2011 and 1,602 workplaces and 11,581 employees from WERS 2011.

Using the REPONSE and WERS surveys, eight dimensions of non-pecuniary job quality can be investigated, although caution should be exercised with regard to comparisons because the wording of the questions is different in the two surveys. Differences in wording partly reflect differences in the institutional context where employees are employed (Coutrot, 1998). Thus, this study takes great care when comparing job quality levels in the two countries.

Responses to questions relating to job quality were coded as $0 / 1$ variables where a code " 1 " indicates the job has a particular attribute while a "0" indicates it is absent. In a number of cases ordinal responses are elicited from the respondent, and the variables have been collapsed into $0-1$ dummy variables. Accordingly, eight 
different aspects of job quality are captured in both surveys as per Table 1 (full details of the survey questions and weighted distributions are presented in Appendix Tables A1-A4. Bivariate correlations between job quality items are presented in Appendix Tables A5-A6). A single job quality index was also constructed by summing the dummy variables, having reverse-coded those dummies capturing poor job quality. The final index runs from zero to eight. Factor analysis was performed to check if there was a single index that could be called job quality. In both countries factor analyses identified a single factor with an eigen value above 1 (2.23 in France and 1.92 in Britain). In France this factor accounts for $96 \%$ of the variance in the eight items and in Britain it accounts for $89 \%$ of the variance.

Table 1 shows the percentage of employees in each survey scoring ' 1 ' on each of the job quality items. Relatively few employees in either country perceived their jobs as insecure, even though the surveys took place not long after the Great Recession. Perceptions of understanding between management and employees were also similar across the two countries, with roughly half giving management positive scores. However, in a number of other respects perceptions of job quality across countries were quite different. Nearly three-quarters of private sector employees in France $(72 \%)$ said they were working under time pressure, compared to only twofifths $(41 \%)$ of British employees. British employees were more likely to say they were free to decide how to work ( $85 \%$ against $67 \%$ in France). Taking all eight items together, the job quality index is higher in Britain than it is in France, running counter to our proposition in our first hypothesis. Of course, this is simply a comparison in mean scores which does not take account of compositional differences in the workforce or the nature of workplaces. Figure 1 shows the distribution of job quality 
on the index score in the REPONSE and WERS surveys. The density plot appears to be more skewed to the right in the WERS rather than in the REPONSE survey.

'FIGURE 1 here'

'TABLE 1 here'

Appendix Table A7 presents the distribution of employees across the firm size distribution in each country. ${ }^{\text {iv }}$ Employees in France are more concentrated in small firms: $24 \%$ are employed in workplaces belonging to firms with between 11 and 49 employees compared with 15\% in Britain. British employees are more concentrated in the largest firms: $31 \%$ are in workplaces which belong to firms with more than 5,000 employees, compared to $16 \%$ in France.

The ILM indicator used in the current study is the one used by Author C (2016) using the same data as the present article does. Workplaces with a strong ILM orientation are those which, for a given gender, age, and education profile within the workforce, sit at or above the median in both the distribution of workplace fixed effects for employee job tenure and the distribution of workplace fixed effects on wages. Appendix Table A8 shows that $13 \%$ of employees in Britain are in workplaces with an 'ILM' orientation whereas in France this is the case for $33 \%$ of employees, confirming that ILMs are more prevalent in France.

Multivariate models were estimated on the additive job quality indicator having transformed it into a standardized z-score with a mean of zero and standard deviation of 1 , which makes it easier to interpret the quantitative association between job quality and various individual and workplace characteristics. 
Ordinary Least Squares models were estimated to capture the variance in job quality across employees in workplaces with different characteristics, based on the following equation.

$$
Y_{i j=} \alpha+\beta X_{i j}+\gamma Z_{j}+\lambda I L M_{j}+\mu F_{j}+\sigma D_{i j}+\varepsilon_{i j}
$$

Where $Y_{i j}$ is the dependent variable job quality of employee $i$ in workplace $j$,

$X_{i j}$ corresponds to the vector of seven demographic and job characteristics namely gender, age (three categories), education (seven categories), union membership, tenure (four categories), type of contract (three categories) and working hours (five categories).

$Z_{j}$ corresponds to the vector of four workplace and firm characteristics, namely single-digit industry (twelve categories), family ownership (25\% threshold, three categories), foreign ownership (two categories), location of the workplace (two categories).

ILM is a dummy variable indicating the existence of ILM in the firm j, and $F$ represents firm size (four categories).

$D_{i j}$ is a dummy variable denoting whether individual $i$ in workplace $j$ is in the REPONSE or WERS survey, and $\sigma$ is the coefficient for that country dummy.

The empirical analysis includes three steps. First equation 1 includes a country dummy to identify the role of the country on non-pecuniary job quality, thus testing hypothesis 1 . In a second step estimations are run separately for each country to test the relationships between individual and firm characteristics (focusing on firm size and ILM) and job quality, and therefore testing hypotheses 2 and 3 . Finally in a third step the same equation is run with eight different dependent variables $\left(Q_{i j}\right.$ which 
are $(0,1)$ dummy dependent variables) corresponding to job quality sub-dimensions.

\section{Results}

Table 2 reports pooled regressions both with and without control variables. Although in terms of production or employment regimes the expectation was that job quality was lower in Britain than in France, the findings show the opposite: average job quality is higher in Britain than in France. Thus the first hypothesis is rejected. These findings are in line with the descriptive statistics presented above. Despite the first hypothesis there is, in fact, other empirical support for this finding Europe (Author B, 2008; Green et al., 2013). It is notable that the differential rises when controls are introduced, from -0.27 to -0.39 , suggesting demographic and workplace traits are more conducive to higher job quality in France than they are in Britain. The -0.39 coefficient indicates that French employees experience job quality that is about twofifths of a standard deviation lower than observationally similar employees in Britain. ${ }^{v}$

The differences between France and Britain on subcomponents of job quality have also been examined, although the direct comparison between job quality items has to be interpreted carefully given differences in the questionnaire items. Table 3 shows that skill development, training participation, job autonomy, work-life balance and relations between employers and employees are perceived as poorer by employees in France than they are in Britain. Job demands are also higher in France than in Britain. The match between the skills possessed by the worker and those required in the job is the only dimension which offers better job quality to French employees. There are no significant differences between France and Britain in relation to job insecurity.

'TABLE 2 here' 


\section{'TABLE 3 here'}

Table 4 provides estimations testing hypotheses 2 and 3 . Before turning to the main results on firm size and ILMs, other results will be briefly discussed that are consistent with our portrayals of France and Britain as different types of employment regime. For example, in France, non-pecuniary job quality is positively correlated with higher levels of education. The finding is consistent with the idea that France has a dualist employment regime in which the more highly educated are able to enter better jobs. In Britain, on the other hand, more highly educated employees report lower job quality, perhaps due to skills mismatch where the expectations of better educated workers do not match the available jobs in the labour market.

In France workplace tenure of less than five years is associated with lower nonpecuniary job quality than being in a workplace ten years or more. This is in line with the expectation that in dualist regimes employees with higher tenure have higher job quality than employees with lower levels of tenure. This does not appear to be the case in Britain, in line with expectations regarding a market-oriented employment regime where the "insider" status conferred by high tenure is less relevant.

Atypical working hours are associated with lower job quality: in France it is parttime workers (30 to 35 hours a week) who suffer lower job quality, while in Britain it is those working long hours (over 41 hours). No association is found to be with temporary or fixed contracts in France, but this may be explained by the fact that short term contracts are not taken into account as the REPONSE survey does not include workers who have been employed for less than 15 months. In Britain those on temporary contracts experience lower job quality. 
Turning to the association between non-pecuniary job quality and workplace features, the focus is on firm size and the presence of ILM. Concerning firm size, the findings show that working in a large firm (5,000 employees and over) decreases job quality, consistent with hypothesis two. However, the negative association between firm size and job quality is confined to these very large firms in France. In Britain, on the other hand, the negative association is significant and apparent for firms as small as 500 employees. The absence of a firm size effect for medium-sized firms in France may be associated with the worker representation rights accorded workers in firms with at least 50 employees.

ILMs are positively associated with job quality in both countries, but the association is only statistically significant in the case of France. This confirms our third hypothesis that ILMs play an important role in the French labour market and favour job quality. Furthermore, in the French case the interaction between ILM and the largest firm size $(10,000$ plus employees) is positive and statistically significant, whereas it is negative and non-significant for Britain, thus confirming our contention in hypothesis three that ILMs would mitigate the negative association between firm size and job quality, but only in the French case. These results show the relevance of considering ILM practices as important drivers of job quality in the French employment regime, and the need to integrate this feature in workplace oriented analyses of job quality. vi

\section{'TABLE 4 here'}

The estimates were also run for each of the eight dimensions of job quality: job demand, job insecurity, job autonomy, manager-employee relation, skills 
development opportunities, training received, skills match and work-life balance. The same controls were used as those in Table 4. The findings relating to firm size and ILMs are presented in Table 5 (for France) and in Table 6 (for Britain). The overall impression from the results is that the associations with firm size and ILMs are quite heterogeneous across dimensions of job quality.

The discussion of results begins by focusing on those two aspects of job quality emphasized in the work of Karasek (1979), namely job demands and job control. Job demands are not significantly associated with firm size in France. However, firm size is positively correlated with job demands in Britain. Job control is lower in larger firms in both countries, consistent with hypothesis two. But once employees are in ILM workplaces in France, job autonomy appears to be higher. This is not the case in Britain.

There is further support for the proposition in hypothesis two that firm size is negatively correlated with job quality. In France, this is the case in relation to poorer opportunities for skill development, greater skills mismatch and adverse effects of work on one's private life. In Britain it is also the case in relation to adverse effects on one's private life, but also poorer employer understanding of employees' needs. The only positive associations between employment by a very large firm and job quality are in relation to lower job insecurity and higher training participation, both of which are confined to France. One possible explanation for this finding is that organized labour has more capacity to influence employment regulation and working conditions in large firms within dualist regimes than in small firms (Holman, 2013; Thelen and Kume, 1999).

In addition to the evidence on job control noted above, there is further evidence that ILMs improve job quality in France: this is apparent in relation to the match 
between worker and job skills, and on reductions in the adverse effects of work, on one's private life, to skill development perspectives, and to better employer understanding of employees' needs. In contrast ILMs do not improve job quality in Britain except on one dimension - they reduce the adverse effects of work on one's private life.

'TABLE 5 here'

'TABLE 6 here'

\section{Conclusion}

Using linked employer-employee data this article has undertaken a comparative study on Britain and France that focuses on the effects of firm size and ILMs on nonpecuniary job quality. Three hypotheses were tested which emanate from the literature on institutional systems in France and Britain. Contrary to the first hypothesis, job quality was higher in Britain than in France: skill development, training participation, job autonomy, work-life balance and relations between employers and employees are all rated more poorly in France than in Britain. Job demands are also higher in France than in Britain. Skills' match to a job is the only dimension which offers better job quality to French employees. There are no significant differences between France and Britain in relation to job insecurity. There was broad support for the second hypothesis, which was that firm size would be negatively associated with job quality in both countries. This was the case when estimating a model for job quality using the additive scale, although analyses of subcomponents of job quality revealed quite a complex picture, with firm size negatively associated with job quality in eight of the sixteen models, positively 
associated with job quality in three of the models, and non-significant in the remaining five models.

There was also broad support for the third hypothesis that ILMs improve job quality in France but not in Britain. Again, the result was apparent for the job quality additive scale though results for the job quality subcomponents were less clear-cut.

There are a number of limitations to this study. It is impossible to tackle the issue of non-random exposure of different sorts of worker to different types of job quality environments. Results may differ somewhat once non-random selection is accounted for. Also it is unclear as to whether poorer perceptions of job quality in large firms reflect objective job quality criteria or whether they simply reflect different reference points of employees in small and large firms. It may be, for instance, that those workers who sort into small firms have fundamentally different expectations to those sorting into larger firms, or else they are different sorts of people whose preferences differ in ways that are difficult to observe. Ideally, it is necessary to observe workers switching firms to establish what role unobserved worker heterogeneity plays, but that is not possible with these cross-sectional data. 


\section{Endnotes}

\section{References}

Clark A and Oswald A J (1996) Satisfaction and Comparison Income. Journal of Public Economics 61: 359-81.

Coutrot T (1998) La force de la loi et le royaume du contrat : une comparaison microstatistique des relations professionnelles en France et en Grande-Bretagne. Travail et Emploi 75: 97-115.

Culpepper P D (1999) The future of the high-skill equilibrium in Germany. Oxford Review of Economic Policy 15 (1): 43-59.

Doeringer P and Piore M (1971) International Labor Market and Manpower Analysis. New York: DC Heath and Company.

Edwards R (1979) Contested Terrain: The Transformation of the Workplace in the 20th Century. New York: Basic Books.

Eyraud F, Marsden D, and Silvestre J (1990) Occupational and internal labour markets in Britain and France. International Labour Review 129 (4): 501-17.

Forth J and Rebérioux A (2016) Workplace Structure and Governance: How Do Employer Differ Between Britain and France. In: Amossé T, Bryson A, Forth J, and Petit H (ed.) Comparative Workplace Employment Relations: An Analysis of Practice in Britain and France. Palgrave Macmillan, 27-60.

Fulton L (2015) Worker representation in Europe. Labour Research Department and ETUI. Available at: http://www.worker-participation.eu/National-Industrial$\underline{\text { Relations. }}$ 
Gallie D (2007) Employment regimes and the quality of work. Oxford University Press, Oxford.

Green F, Mostafa A, Parent-Thirion A, Vermeylen G, Van Houten G, Biletta I, et al. (2013) Is Job Quality Becoming More Unequal?. Industrial and Labour Relations Review 66 (2): 753-794.

Greenhalgh C (1999) Adult Vocational Training and Government Policy in France and Britain. Oxford Review of Economic Policy 15 (1): 97-113.

Green F (2013) Is Britain such a bad place to work? The level and dispersion of job quality in comparative European perspective. Centre for Learning and Life Chances in Knowledge Economies and Societies. Available at: http///www.llakes.org.

Holman D (2013) An Explanation of Cross-national Variation in call centre job quality using institutional theory. Human Relations 27 (1): 21-38.

Hyman R (2001) Understanding European Trade Unionism: Between Market, Class and Society. London: Sage.

Karasek J R A (1979) Job demands, job decision latitude, and mental strain: Implications for job redesign. Administrative Science Quarterly: 285-308.

Marsden D (1990) Institutions and labour mobility: occupational and internal labour markets in Britain, France, Italy, and West Germany. In Brunetta R and Dell'Aringa (eds.) Labour relations and economic performance (Macmillan, London).

Maurice M, Sellier F and Silvestre J J (1986) The Social Foundations of Industrial Power. Cambridge, Mass.: MIT Press. 
Ok W and Tergeist P (2003) Improving Worker's Skills: Analytical Evidence and the Role of the Social Partners. OECD Social, Employment and Migration Working Papers: 10, Paris.

Oi W Y and Idson T L (1999) Firm size and wages. In Ashenfelter O C and Card D (eds.) Handbook of Labor Economics. 3, Part B: 2165-2214.

Osterman P (2013) Introduction to the special issue on job quality. Industrial and Labor Relations Review 66 (4): 739-752.

Oswald A J, Proto E. and Sgroi D (2015) Happiness and Productivity. Journal of Labor Economics 33 (4): 789-822.

Paul J (1992) Le congé individuel de formation dans les trajectoires professionnelles. Formation Emploi 39: 55-75.

Piore M J (1978) Dualism in the labor market, A response to uncertainty and flux, The case of France. Revue Economique 29: 26-48.

Tansel A and Gazioglu S (2013) Management Employee Relations, Firm Size and Job Satisfaction. IZA Discussion Paper Series No. 7308.

Thelen K and Kume I (1999) The effects of globalization on labor revisited: lessons from Germany and Japan. Politics and Society 27(4): 477-505.

Trésor-Eco (2016) '30 years of modernizing social relations'. January, 160. 
Figure 1. The distribution of job quality index in Britain and France

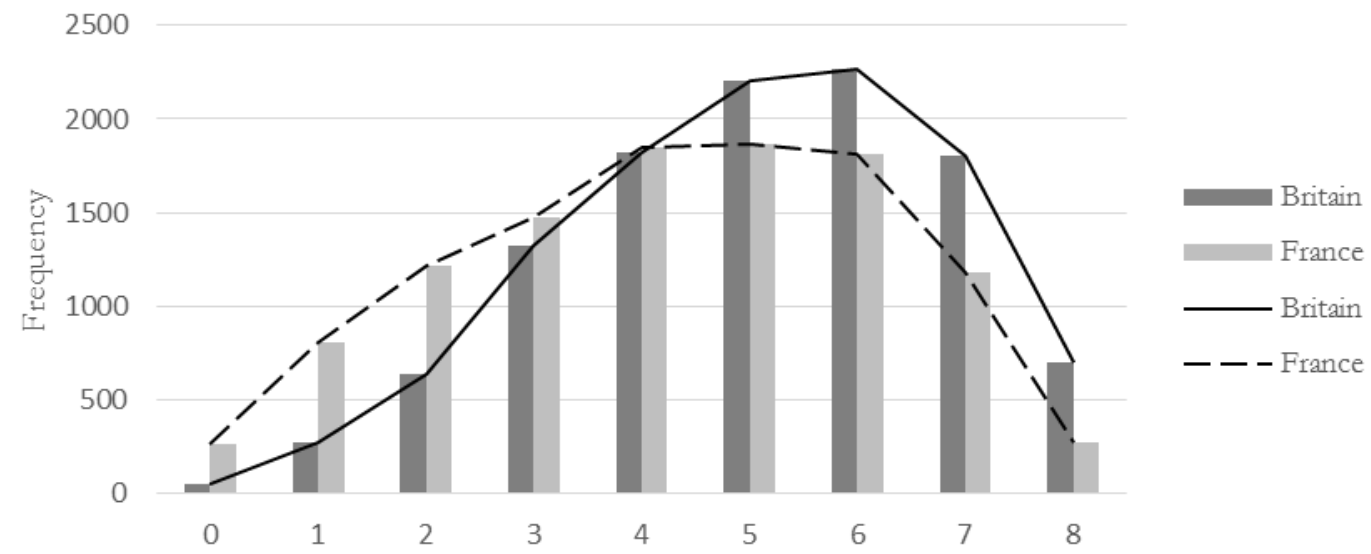

Notes: Figure is weighted. Job quality is based on 8-point item scale. The scales for job quality range from 0 (low) to +8 (high).

Base: All employees with at least one year's tenure, in private workplaces with 11 or more employees, and no missing data on job quality

Table 1. Employee Job Quality in Britain and France in 2011.

Job insecurity

Work intensity

Job autonomy

Training participation

Skill development

Employee -employer relations

Skills matched to job

Adverse effects of work on one's private life

Job quality additive index $(0,8)$

$\mathrm{N}$

Country

\begin{tabular}{c|c} 
WERS & REPONSE \\
\hline $16(0.37)$ & $16(0.37)$ \\
$41(0.49)$ & $72(0.45)$ \\
$85(0.35)$ & $67(0.47)$ \\
$52(0.50)$ & $46(0.50)$ \\
$56(0.50)$ & $43(0.50)$ \\
$55(0.50)$ & $51(0.50)$ \\
$44(0.50)$ & $63(0.48)$ \\
$29(0.45)$ & $36(0.48)$ \\
$5,02(1.76)$ & $4,25(1.96)$ \\
\hline 11,581 & 11,244 \\
\hline Britain & France
\end{tabular}
for job quality range from 0 (low) to +8 (high). Standard deviation in parentheses. The mean value of job quality index sums the scores for all eight items having reverse-coded those dummy variables identifying poor job quality.

Base: All employees with at least one year's tenure, in private workplaces with 11 or more employees, and no missing data on job quality. 
Table 2. Job Quality (in standardized z-score) in Britain and France

\section{Constant}

REPONSE (Ref: WERS)

Male (Ref:: Female)

Age: 16-29 (Ref. 30-49)

$50+$

Education: Level 2 (Ref.: Level 0/1)

Level 3

Level 5B

Level $5 \mathrm{~A}$ short $/ \mathrm{med}$

Level 5A Long/6

Union member: yes (Ref:: no)

Tenure: less than 5 (Ref.: 10+)

5 to 10 years

Hours: 0-29 (Ref.: 36-40)

30-35

41-49

$50+$

Contract: temporary (Ref.: permanent)

Fixed

Firm size: 50-499 (Ref.: less than 50)

500-4,999

5,000 and more

ILM workplace: yes (Ref.: no)

Industry: Energy (Ref. : Manufacturing)

Construction

Wholesale and retail

Hotel and restaurants

Transport and communication

Financial services

Other business

Education

Health

Other community services

Family ownership: 25\% of equity capital

Foreign ownership

Capital city: yes (Ref. no)

R-squared

Observations

Number of workplaces

\begin{tabular}{cc}
\multicolumn{2}{c}{ Model 1 } \\
\hline $0.11^{* * *}$ & $(0.03)$ \\
$\mathbf{- 0 . 2 7} * * *$ & $\mathbf{( 0 . 0 3 )}$
\end{tabular}

Model 2

$0.18^{* * *} \quad(0.06)$

$\mathbf{- 0 . 3 9 * * *} \quad(\mathbf{0 . 0 3})$

$-0.01$

$0.05 *$

0.06

0.01

0.02

$0.16^{* * *}$

0.02

$0.24 * * *$

$-0.01 \quad(0.03)$

$0.002 \quad(0.03)$

$-0.09 * * * \quad(0.03)$

$-0.10^{* * *} \quad(0.03)$

$-0.17 * * * \quad(0.04)$

$-0.11$

$(0.13)$

$-0.04$

$-0.05$

$-0.08 * *$

$-0.12^{* * *}$

$0.19 * * *$

$0.44 * * *$

$0.22 * * *$

0.07

0.04

$-0.002$

$0.17 * *$

$0.14 * * *$

0.07

$0.30^{* * *}$

$0.12^{*}$

$-0.10^{* * * *}$

$-0.05$

0.04

0.07

15,563

3,897

Notes: Weighted pooled OLS regressions. Dummies for missing observations are not presented. Standard errors in parentheses. The job quality index is presented in Section 3. Model 1 presents raw differences and Model 2 contains control variables. $* * * \mathrm{p}<0.01 ; * * \mathrm{p}<0.05 ; \mathrm{p}<0.1$.

Base: All employees in the REPONSE (2011) and WERS (2011) surveys with at least one year's tenure, in private workplaces with 11 or more employees, with no missing data on job quality 
Table 3. Subcomponents of job quality in the pooled data

\begin{tabular}{ll|l|l|l|l|l|l|l}
\hline & $\begin{array}{l}\text { Job } \\
\text { demands }\end{array}$ & Insecurity & $\begin{array}{l}\text { Skill } \\
\text { development }\end{array}$ & $\begin{array}{l}\text { Skills } \\
\text { match to } \\
\text { a job }\end{array}$ & $\begin{array}{l}\text { Training } \\
\text { participation }\end{array}$ & $\begin{array}{l}\text { Job } \\
\text { autonomy }\end{array}$ & $\begin{array}{l}\text { Adverse } \\
\text { effects } \\
\text { work on one's } \\
\text { private life }\end{array}$ & $\begin{array}{l}\text { Employee } \\
\text {-employer } \\
\text { relations }\end{array}$ \\
\hline Constant & $\begin{array}{l}0.33^{* * *} \\
(0.03)\end{array}$ & $\begin{array}{l}0.15^{* * *} \\
(0.03)\end{array}$ & $\begin{array}{l}0.49^{* * *} \\
(0.03)\end{array}$ & $\begin{array}{l}0.57 * * * \\
(0.03)\end{array}$ & $\begin{array}{l}0.28^{* * *} \\
(0.03)\end{array}$ & $\begin{array}{l}0.86^{* * *} \\
(0.02)\end{array}$ & $\begin{array}{l}0.14^{* * *} \\
(0.02)\end{array}$ & $\begin{array}{l}0.55^{* * *} \\
(0.03)\end{array}$ \\
$\begin{array}{l}\text { REPONSE } \\
\text { Ref.: }\end{array}$ & $0.35^{* * *}$ & 0.01 & $-0.15^{* * *}$ & $0.18^{* * *}$ & $-0.05 * * *$ & $-0.21^{* * *}$ & $0.13^{* * *}$ & $-0.07 * * *$ \\
WERS & $(0.01)$ & $(0.01)$ & $(0.01)$ & $(0.01)$ & $(0.01)$ & $(0.01)$ & $(0.01)$ & $(0.014)$ \\
\hline R2 & 0.14 & 0.02 & 0.07 & 0.06 & 0.09 & 0.10 & 0.08 & 0.03 \\
\hline N obs & 18,512 & 16,249 & 18,538 & 18,597 & 18,483 & 18,578 & 18,625 & 18,514 \\
N wkplaces & 4,169 & 3,942 & 4,167 & 4,167 & 4,154 & 4,166 & 4,168 & 4,163 \\
\hline
\end{tabular}

Notes: Weighted pooled OLS regressions. Models control for individual and workplace job characteristics as discussed in the text. Standard errors in parentheses. Statistical significance is denoted by *** $p<0.01 ; * * p<0.05 ; p<0.1$

Base: All employees in the REPONSE (2011) and WERS (2011) surveys with at least one year's tenure in private workplaces with 11 or more employees, with no missing data on job quality. 
Table 4. Job Quality (in standardized z-score) and Firm size in France and Britain.

\section{Constant}

Gender: male (Ref. female)

Age 16-29 (Ref: 31-49)

$50+$

Education: Level 2 (Ref: Level 0/1)

Level 3

Level5B

Level 5A short

Level 5A long

Tenure: Less than 5 years (Ref: more than 10 years)

5 to 10 years

Hours: 0-29 hours per week (Ref: 36-40 hours per week)

30-35

41-49

$50+$

Contract: Temporary (Ref: permanent)

Fixed

Union member: yes

Firm size: 50-499 (Ref.: less than 50)

500-4999

5000 and more

ILM workplace: yes (Ref. no)

Industry: Energy (Ref: manufacturing)

Construction

Wholesale and retail

Hotels and restaurants

Transport and communication

Financial services

Other business

Education

Health

Other community services

Family ownership: $25 \%$ of equity capital

Foreign ownership: yes (Ref. no)

Capital city: yes (Ref.: no)

\section{France (REPONSE) Britain (WERS)}

$-0.39 * * * \quad(0.08)$

$0.43 * * * \quad(0.09)$

0.05

$(0.03)$

$(0.04)$

0.04

(0.04)

$(0.04)$

0.03

$(0.12)$

$(0.05)$

0.12

(0.09)

$0.18 * * *$

(0.05)

$0.39 * * * \quad(0.06)$

$0.31 * * * \quad(0.07)$

$0.50 * * *$

(0.07)

$-0.04$

)

$-0.09 *$

(0.05)

0.004

(0.04)

$-0.08$

(0.06)

$-0.09 * *$

$(0.04)$

(0.04)

$-0.01$

$-0.08$

(0.05)

0.16

(0.23)

$-0.001$

$-0.25 * * *$

(0.08)

(0.05)

$-0.06$

(0.04)

$-0.01$

(0.05)

$-0.09 *$

(0.06)

$0.22 * * *$

(0.04)

$0.47 * * *$

(0.17)

$0.25^{* * *} *$

$(0.07)$

0.07

$-0.01$

0.02

(0.05)

(0.14)

(0.06)

0.12

$0.12 * *$

(0.09)

(0.05)

$-0.08$

(0.24)

$0.28 * * *$

(0.06)

$0.21 * *$

(0.09)

$-0.16 * * *$

(0.04)

$-0.13 * *$

$(0.06)$

(0.04)

0.06

(0.06)

$-0.20 * * *$

$0.14 * *$

(0.05)

$-0.23 * * *$

0.06

(0.05)

(0.04)

(0.06)

$(0.14)$

(0.08)

(0.05)

(0.06)

(0.06)

(0.06)

(0.11)

(0.09)

(0.08)

$(0.09)$

(0.10)

(0.11)

(0.07)

(0.09)

$-0.02$

(0.06)

R-squared

Observations

0.07

Number of workplaces

7,023

2,935

Notes: Weighted OLS regressions. Dummies for missing observations are not presented. Standard errors in parentheses. The index of job quality is presented in the section 3 . ${ }^{* * *} \mathrm{p}<0.01 ;{ }^{* *} \mathrm{p}<0.05 ; \mathrm{p}<0.1$.

Base: All employees in the REPONSE (2011) and WERS (2011)surveys with at least one year's tenure, in private workplaces with 11 or more employees, with no missing data on job quality 
Table 5. Subcomponents of job quality in France

\begin{tabular}{|c|c|c|c|c|c|c|c|c|}
\hline & $\begin{array}{l}\text { Job } \\
\text { demand }\end{array}$ & Insecurity & $\begin{array}{l}\text { Skill } \\
\text { development }\end{array}$ & $\begin{array}{l}\text { Skills' match } \\
\text { to a job }\end{array}$ & $\begin{array}{l}\text { Training } \\
\text { participation }\end{array}$ & $\begin{array}{l}\text { Job } \\
\text { autonomy }\end{array}$ & $\begin{array}{l}\text { Adverse } \\
\text { effects of } \\
\text { work on } \\
\text { one's } \\
\text { private life }\end{array}$ & $\begin{array}{l}\text { Employee- } \\
\text { employer } \\
\text { relation }\end{array}$ \\
\hline ILM (Ref:: no) yes & $\begin{array}{l}-0.14 \\
(0.013)\end{array}$ & \begin{tabular}{|c|}
-0.02 \\
$(0.01)$
\end{tabular} & $\begin{array}{l}0.08^{* * *} \\
(0.01)\end{array}$ & $\begin{array}{l}0.07^{* * *} \\
(0.02)\end{array}$ & $\begin{array}{l}0.09 * * * \\
(0.01)\end{array}$ & $\begin{array}{l}0.04 * * * \\
(0.01)\end{array}$ & $\begin{array}{l}-0.04 * * * \\
(0.01)\end{array}$ & $\begin{array}{l}0.04^{* * *} \\
(0.02)\end{array}$ \\
\hline Constant & $\begin{array}{l}0.70^{* * *} \\
(0.03)\end{array}$ & $\begin{array}{l}0.19^{* * *} \\
(0.03)\end{array}$ & $\begin{array}{l}0.26^{* * *} \\
(0.03)\end{array}$ & $\begin{array}{l}0.69^{* * * *} \\
(0.03)\end{array}$ & $\begin{array}{l}0.25^{* * *} \\
(0.03)\end{array}$ & $\begin{array}{l}0.61 * * * \\
(0.03)\end{array}$ & $\begin{array}{l}0.30^{* * * *} \\
(0.03)\end{array}$ & $\begin{array}{l}0.44^{* * *} \\
(0.03)\end{array}$ \\
\hline $\begin{array}{l}\text { R2 } \\
\text { Number of employees } \\
\text { Number of workplaces }\end{array}$ & $\begin{array}{l}0.04 \\
9,465 \\
3,205\end{array}$ & $\begin{array}{l}0.03 \\
7,341 \\
2,977\end{array}$ & $\begin{array}{l}0.09 \\
9,459 \\
3,202\end{array}$ & $\begin{array}{l}0.05 \\
9,443 \\
3,202\end{array}$ & $\begin{array}{l}0.09 \\
9,346 \\
3,189\end{array}$ & $\begin{array}{l}0.07 \\
9,463 \\
3,201\end{array}$ & $\begin{array}{l}0.07 \\
9,464 \\
3,203\end{array}$ & $\begin{array}{l}0.03 \\
9,433 \\
3,198\end{array}$ \\
\hline
\end{tabular}

Notes: Weighted OLS regressions. Dummies for missing observations are not presented. All models control for individual and workplace job characteristics. Standard errors in parentheses. Statistical significance denoted by $* * * \mathrm{p}<0.01 ; * * \mathrm{p}<0.05 ; \mathrm{p}<0.1$.

Base: All employees in the REPONSE (2011) survey with at least one year's tenure in private workplaces with 11 or more employees, with no missing data on job quality. 
Table 6. Subcomponents of job quality in Britain

\begin{tabular}{|c|c|c|c|c|c|c|c|c|}
\hline & $\begin{array}{l}\text { Job } \\
\text { demand }\end{array}$ & Insecurity & $\begin{array}{l}\text { Skill } \\
\text { development }\end{array}$ & $\begin{array}{l}\text { Skills' match } \\
\text { to a job }\end{array}$ & $\begin{array}{l}\text { Training } \\
\text { participation }\end{array}$ & $\begin{array}{l}\text { Job } \\
\text { autonomy }\end{array}$ & $\begin{array}{l}\text { Adverse } \\
\text { effects of } \\
\text { work on } \\
\text { one's } \\
\text { private life }\end{array}$ & $\begin{array}{l}\text { Employee- } \\
\text { employer } \\
\text { relation }\end{array}$ \\
\hline ILM (Ref.: no) yes & $\begin{array}{l}0.02 \\
(0.03)\end{array}$ & \begin{tabular}{|c|}
-0.01 \\
$(0.02)$
\end{tabular} & $\begin{array}{l}0.01 \\
(0.03)\end{array}$ & $\begin{array}{l}0.02 \\
(0.02)\end{array}$ & $\begin{array}{l}0.04 \\
(0.03)\end{array}$ & $\begin{array}{l}0.02 \\
(0.02)\end{array}$ & $\begin{array}{l}-0.03^{*} \\
(0.02)\end{array}$ & $\begin{array}{l}0.02 \\
(0.03)\end{array}$ \\
\hline Constant & $\begin{array}{l}0.31^{* * *} \\
(0.04)\end{array}$ & $\begin{array}{l}0.10^{* * *} \\
(0.04)\end{array}$ & $\begin{array}{l}0.64^{* * *} \\
(0.05)\end{array}$ & $\begin{array}{l}0.68^{* * *} \\
(0.04)\end{array}$ & $\begin{array}{l}0.26^{* * *} \\
(0.05)\end{array}$ & $\begin{array}{l}0.94^{* * *} \\
(0.03)\end{array}$ & $\begin{array}{l}0.09^{* * *} \\
(0.03)\end{array}$ & $\begin{array}{l}0.64^{* * *} \\
(0.04)\end{array}$ \\
\hline $\begin{array}{l}\text { R2 } \\
\text { Number of employees } \\
\text { Number of workplaces }\end{array}$ & $\begin{array}{l}0.07 \\
9,047 \\
964\end{array}$ & $\begin{array}{l}0.05 \\
8,908 \\
965\end{array}$ & $\begin{array}{l}0.04 \\
9,079 \\
965\end{array}$ & $\begin{array}{l}0.03 \\
9,154 \\
965\end{array}$ & $\begin{array}{l}0.10 \\
9,137 \\
965\end{array}$ & $\begin{array}{l}0.04 \\
9,115 \\
965\end{array}$ & $\begin{array}{l}0.11 \\
9,161 \\
965\end{array}$ & $\begin{array}{l}0.05 \\
9,081 \\
965\end{array}$ \\
\hline
\end{tabular}

Notes: Weighted OLS regressions. Dummies for missing observations are not presented. All models control for individual and workplace job characteristics. Standard errors in parentheses. Statistical significance denoted by $* * * \mathrm{p}<0.01 ; * * \mathrm{p}<0.05 ; \mathrm{p}<0.1$.

Base: All employees in the WERS (2011) survey with at least one year's tenure in private workplaces with 11 or more employees, with no missing data on job quality. 


\section{Appendices}

A1. Job Quality variables in the WERS survey

\begin{tabular}{|c|c|c|c|c|c|}
\hline & $\begin{array}{l}\text { Strongly } \\
\text { agree }\end{array}$ & Agree & $\begin{array}{l}\text { Neither } \\
\text { agree nor } \\
\text { disagree }\end{array}$ & Disagree & $\begin{array}{l}\text { Strongly } \\
\text { disagree }\end{array}$ \\
\hline $\begin{array}{l}\text { Job demand } \\
\text { I never seem to have enough time to get my } \\
\text { work done }(\mathrm{N}=11,333)\end{array}$ & $\begin{array}{l}\text { Code } \\
14\end{array}$ & 27 & & 25 & 3 \\
\hline $\begin{array}{l}\text { Employee-employer relations } \\
\text { Managers are sincere in attempting to } \\
\text { understand employees' views }(\mathrm{N}=11,370)\end{array}$ & 11 & 43 & 24 & 15 & 6 \\
\hline $\begin{array}{l}\text { Skill development } \\
\text { Managers encourage to develop their skills } \\
(\mathrm{N}=11,351)\end{array}$ & 13 & 42 & 26 & 13 & 6 \\
\hline \multirow[t]{3}{*}{$\begin{array}{l}\text { Adverse effects of work on one's private } \\
\text { life } \\
\text { I often find it difficult to fulfill my } \\
\text { commitments outside of work because of the } \\
\text { amount of time I spend on my job }(\mathrm{N}=11,506)\end{array}$} & 9 & 20 & 25 & 37 & 9 \\
\hline & $\begin{array}{l}\text { Strongly } \\
\text { agree }\end{array}$ & Agree & $\begin{array}{l}\text { Neither } \\
\text { agree nor } \\
\text { disagree }\end{array}$ & Disagree & $\begin{array}{l}\text { Strongly } \\
\text { disagree }\end{array}$ \\
\hline & \multicolumn{2}{|c|}{ Coded 0} & & \multicolumn{2}{|c|}{ Coded 1} \\
\hline $\begin{array}{l}\text { Job insecurity } \\
\text { I feel my job is secure in this workplace } \\
(\mathrm{N}=11,147)\end{array}$ & 17 & 46 & 21 & 12 & 4 \\
\hline $\begin{array}{l}\text { Notes: Weighted frequencies in cells in percenta } \\
\text { they never seemed to have enough time to get their } \\
\text { Base: All employees with at least one year of te } \\
\text { with no missing data on job quality. }\end{array}$ & $\begin{array}{l}\text { ork } 14 \% \text { of } \\
\text { ork done. } \\
\text { ure, in priv }\end{array}$ & mployee & rkported that th & 1 or more & $\begin{array}{l}\text { agreed that } \\
\text { employees, }\end{array}$ \\
\hline
\end{tabular}


Training participation: Apart from health and safety training, how much training have you had during the last 12 months, either paid or organized by your employer?

None

Less than 1 day

1 to less than 2 days

2 to less than 5 days

5 to less than 10 days

10 days and more

$\mathrm{N}=11,468$

Skills' match to a job: How well do the work skills you personally have match the skills you need to do your present job?

Much higher 20

A bit higher $\quad 32$

About the same 44

A bit lower 4

Much lower 1

$\mathrm{N}=11,489$

Job autonomy: In general, how much influence do you have over how to do your work?

A lot

Some

A little

54

31

None

$\mathrm{N}=11,446$

Notes: frequencies in cells in percentages. $34 \%$ of employees reported that they had no training in the last 12 months, $20 \%$ of employees reported that their skills are much higher than the present job they had, and $54 \%$ of employees reported that they had a lot of influence over their work.

Source: WERS (2011) survey. 
A3. Job Quality variables in the REPONSE survey

\begin{tabular}{|c|c|c|c|c|}
\hline & Always & Often & Sometimes & Never \\
\hline & \multicolumn{2}{|c|}{ Coded 1} & \multicolumn{2}{|c|}{ Coded 0} \\
\hline $\begin{array}{l}\text { Job demand: In your work, is there } \\
\text { any time pressure? }(\mathrm{N}=11,160)\end{array}$ & 31 & 41 & 25 & 2 \\
\hline $\begin{array}{l}\text { Adverse effects of work on one's } \\
\text { private life } \\
\text { Does your work allow you to organize } \\
\text { your private life satisfactorily? }(\mathrm{N}=11,179)\end{array}$ & 18 & 45 & 30 & 6 \\
\hline $\begin{array}{l}\text { Job autonomy: Are you free to decide } \\
\text { how to do your work? }(\mathrm{N}=11,161)\end{array}$ & 20 & 47 & 23 & 10 \\
\hline $\begin{array}{l}\text { Skills' match to a job: In your work, } \\
\text { are you fully able to use your skills? } \\
N=11,132\end{array}$ & 19 & 45 & 30 & 7 \\
\hline $\begin{array}{l}\text { Skill development: Does your work } \\
\text { enable you to learn new things? } N=11,147\end{array}$ & 11 & 32 & 45 & 12 \\
\hline $\begin{array}{l}\text { Employee-employer relations: Does } \\
\text { your line manager pay attention to what you } \\
\text { say? }(\mathrm{N}=11,115)\end{array}$ & 15 & 36 & 39 & 10 \\
\hline \multicolumn{5}{|c|}{$\begin{array}{l}\text { Notes: Weighted frequencies in cells in percentages. } 18 \% \text { of employees reported that work } \\
\text { always allowed them to organize private life satisfactorily. }\end{array}$} \\
\hline
\end{tabular}

A4. Other job quality variables in the REPONSE survey

\begin{tabular}{l} 
A4. Other job quality variables in the REPONSE survey \\
\cline { 2 - 2 } Training participation: During the last three years, have you undertaken any vocational training financed by \\
your employer? (REPONSE survey) \\
Yes \\
No \\
N=11,002
\end{tabular}


A5: Correlation matrix of job quality measures in the REPONSE survey

1. Free to decide how to work

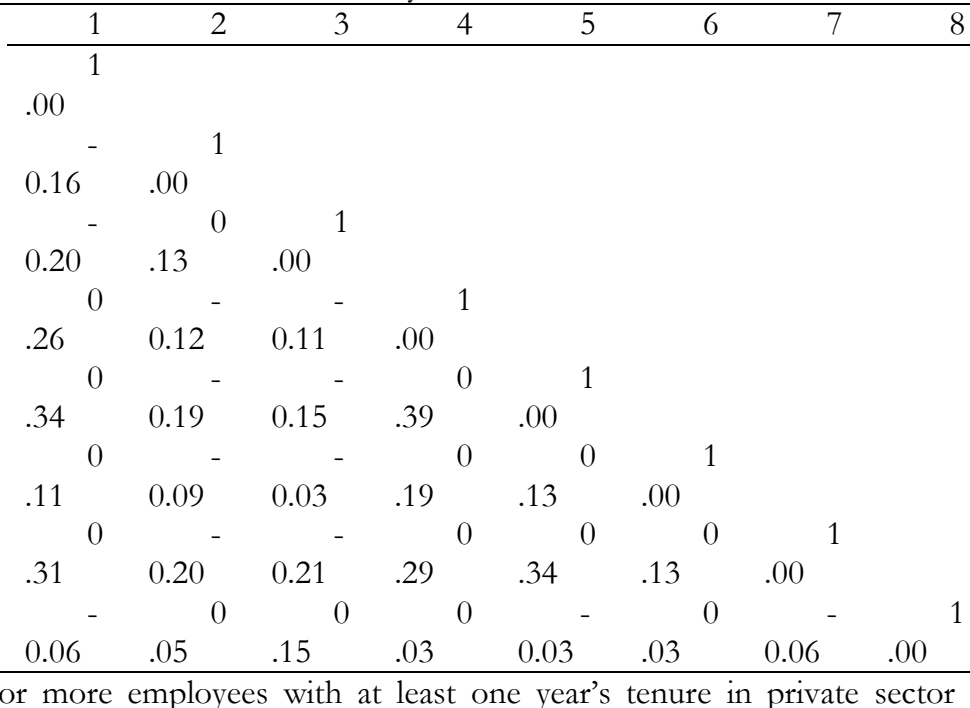

2. Believes job is not secure

3. Work adversely affects private life

4. Able to learn or develop skills

5. Skills matched to job

6. Training received

7. Manager pays attention/understands employees

8. Working under time pressures

Base: Employees of all firms with 11 or more employees with at least one year's tenure in private sector workplace. $\mathrm{N}=8,201$

A6: Correlation matrix of job quality measures in the WERS survey

1. Free to decide how to work

.00

2. Believes job is not secure

3. Work adversely affects private life

4. Able to learn or develop skills

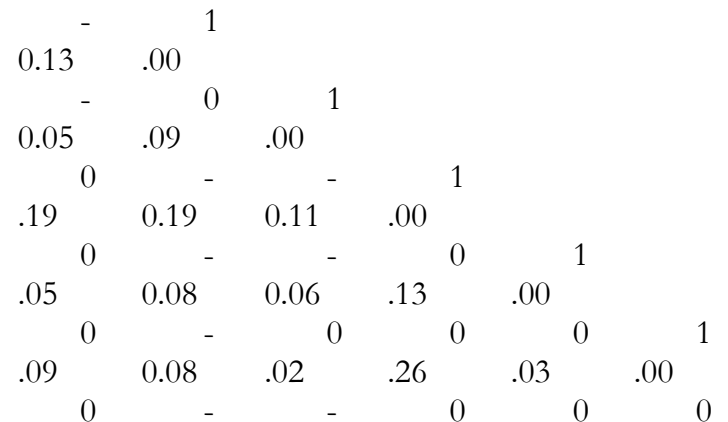

7. Manager pays attention/understands employees

5. Skills matched to job

$\begin{array}{llll}.19 & 0.22 & 0.13 & .51\end{array}$

8. Working under time pressures

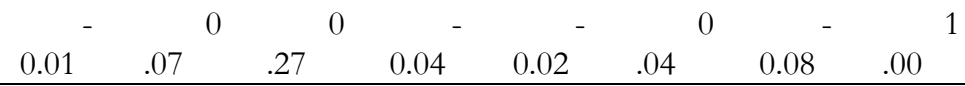

Base: Employees of all firms with 11 or more employees with at least one year's tenure in private sector workplace. $\mathrm{N}=10,592$ 
A7: The distribution of employees across firm size in the WERS and REPONSE surveys

\begin{tabular}{lll}
\hline & Britain (WERS) & France (REPONSE) \\
\hline $11-49$ & $15 \%$ & $24 \%$ \\
$50-499$ & $23 \%$ & $34 \%$ \\
$500-4,999$ & $29 \%$ & $25 \%$ \\
5,000 and more & $31 \%$ & $16 \%$ \\
Missing & $2 \%$ & $1 \%$ \\
\hline N & 11,581 & 11,244 \\
\hline Notes: Weighted frequencies in cells in percentages. \\
\hline Base: All employees with at least one year of tenure, in private sector workplaces with 11 or more \\
employees,
\end{tabular}

A8: The share of employees in workplaces with an ILM orientation in the WERS and REPONSE surveys

\begin{tabular}{ll|l}
\hline & Britain (WERS) & France (REPONSE) \\
\hline Yes & $13 \%$ & $33 \%$ \\
No & $80 \%$ & $65 \%$ \\
Missing & $7 \%$ & $2 \%$ \\
\hline N & 11,581 & 11,244 \\
\hline
\end{tabular}

Notes: In the WERS survey 13\% of employees are in workplaces which have an 'ILM' orientation in the WERS survey. The ILM orientation of the workplace is defined by Forth et al. (2016) as the share of workplaces with high levels of job tenure and the payment of above market wages.

Base: All employees with at least one year of tenure, in private sector workplaces with 11 or more employees

i To keep their institutional power resources, unions, de facto, defend the two-tier labour market reforms as their preferences are dependent on the institutional context (Davidsson and Emmenegger, 2013). When involved in negotiations relating to job security legislation, for instance, unions' main aim has traditionally been to maintain the protection given to workers on permanent contracts, sometimes to the disadvantage of those on temporary employment contracts.

ii https://www.gov.uk/training-study-work-your-rights

iii For details of both surveys see Author C (2016).

iv The data contain both firm size and workplace size, which are not used interchangeably. They are identical for single-workplace firms.

$\checkmark$ The raw estimate of the country dummy variable in a reduced sample size has also been run, and the coefficient is -0.28 . This confirms that the shift in the 
coefficient is due to the additional control variables rather than the change in sample size that occurs when we introduce them.

vi Author A (2016) show ILMs are also relevant to the study of workplace HR practices. In the estimations run for the present article, industry and some ownership information have also been introduced in the workplace variables. Similar industry effects appear in France and Britain: compared to manufacturing, energy, construction, health, and business services have significantly higher job quality. Employment in a family-owned business is associated with lower non-pecuniary job quality in France but not in Britain. Forth and Rebérioux (2016) also show the existence of a wage penalty in family-owned firms. Furthermore, the results show that employment in foreign-owned business is associated with lower non-pecuniary job quality in France, but not in Britain. 